\title{
EKSTRAKSI GELATIN DARI KULIT IKAN PATIN (Pangasius hypopthalmus) SECARA PROSES ASAM
}

\author{
Rosmawaty Peranginangin *' Nurul Haq"), Widodo Farid Ma'ruf') dan Arham Rusli“)
} \begin{abstract}
ABSTRAK
Ekstraksi gelatin dari kulit ikan patin (Pangasius hypopthalmus) telah dilakukan dengan perlakuan perendaman kulit dalam asam sitrat dalam berbagai $\mathrm{pH}$ yaitu: 2, 3 dan 4 dengan variasi lama perendaman 12, 24 dan 36 jam. Kulit kemudian dicuci sampai pH netral dan gelatin diekstraksi pada suhu 70 dan $90^{\circ} \mathrm{C}$ selama 2 jam. Filtrat dikeringkan dalam oven suhu $50^{\circ} \mathrm{C}$ selama 36-48 jam sehingga diperoleh lembaran gelatin. Penentuan perlakuan yang terbaik untuk ekstraksi gelatin dipilih berdasarkan rendemen, viskositas, kekuatan gel dan $\mathrm{pH}$ gelatin. Hasil penelitian menunjukkan bahwa perlakuan perendaman dalam asam sitrat pH 3 selama 12 jam, suhu ekstraksi $90^{\circ} \mathrm{C}$ selama 2 jam memberikan hasil yang terbaik yang diperlihatkan dari rendemen $9,36 \%$, viskositas $10,1 \mathrm{cps}$, kekuatan gel 202,55 bloom dan $\mathrm{pH} 6,7$.
\end{abstract}

\section{ABSTRACT: Extraction of gelatin from catfish (Pangasius hypopthalmus) skin by acid process. By: Rosmawaty Peranginangin, Nurul Haq, W. F. Ma'ruf and Arham Rusli}

Gelatin extraction from catfish (Pangasius hypopthalmus) skin has been conducted. Treatments applied were soaking catfish skin in citric acid solution at various $\mathrm{pH}(2,3$, and 4) and soaking time (12, 24 and 36 hours). The skin was then washed untill a neutral $\mathrm{pH}$ and extracted at $70^{\circ} \mathrm{C}$ and $90^{\circ} \mathrm{C}$ for 2 hours. Filtrate was then dried in an oven at $50^{\circ} \mathrm{C}$ for $36-48$ hours to form gelatin sheet. The best treatment of gelatin extraction was selected based on the yield, viscosity, gel strength and $\mathrm{pH}$ of gelatin produced. The result showed that soaking the skin in citric acid solution at $\mathrm{pH} 3$ for 12 hours gave the best result with $9.36 \%$ yield, $10.1 \mathrm{cps}$ viscosity, 202.55 bloom gel strength and $\mathrm{pH} 6.7$.

KEYWORDS: gelatin, acid, catfish, skin, and extraction

\section{PENDAHULUAN}

Gelatin adalah suatu protein murni yang termasuk dalam bahan tambahan makanan, diperoleh dari kolagen yang didenaturasi secara panas. Gelatin mempunyai titik leleh di bawah $35^{\circ} \mathrm{C}$, di bawah suhu tubuh manusia, yang membuat produk gelatin mempunyai karakteristik yang unik bila dibandingkan dengan bahan pembentuk gel lainnya seperti pati, alginat, pektin, agar dan karaginan yang merupakan senyawa karbohidrat (Gomez \& Montero, 2001).

Beberapa penelitian mengenai gelatin yang diekstrak dari kulit ikan telah dilakukan, namun masih terbatas pada jenis-jenis ikan laut seperti cucut, pari, paus dan tuna (Pelu et al., 1998; Yustika, 2000; Gomez \& Montero, 2001; Astawan et al., 2002). Riset mengenai ekstraksi gelatin dari kulit ikan air tawar belum banyak dilakukan. Oleh karena itu diperlukan suatu penelitian tentang teknik ekstraksi gelatin dari kulit ikan patin, agar limbah yang dihasilkan dari produksi fillet dapat lebih termanfaatkan.
Kulit ikan umumnya terdiri dari dua lapisan utama yaitu epidermis dan dermis. Lapisan dermis merupakan jaringan pengikat yang cukup tebal yang mengandung sejumlah serat-serat kolagen. Kulit ikan mengandung air $69,6 \%$, protein $26,9 \%$, abu $2,5 \%$ dan lemak $0,7 \%$ (Kimura et al., 1988). Kandungan protein pada kulit hampir sama dengan kandungan protein daging (Sato et al., 1991).

Untuk mengubah kolagen menjadi gelatin diperlukan perlakuan yang dapat memecah ikatan nonkovalen untuk merusak struktur protein sehingga dihasilkan pengembangan protein dan yang dapat memecah ikatan intra dan intermolekuler sehingga mengakibatkan kolagen larut (Gomez \& Montero, 2001). Ikatan silang kolagen pada kulit ikan labil terhadap asam (Montero et al., 1990; 1995) sehingga dengan konsentrasi asam yang sedang saja sudah dapat larut (Norland, 1990).

Perusahaan-perusahaan yang memproduksi gelatin mutu pangan dari kulit ikan kebanyakan menggunakan asam sitrat karena asam ini tidak

Peneliti dari Pusat Riset Pengolahan Produk dan Sosial Ekonomi Kelautan dan Perikanan

Mahasiswa Pascasarjana dari Teknologi Pascapanen Institut Pertanian Bogor 
menyebabkan perubahan warna dan bau pada gelatin (Grosman \& Bergman, 1991; Gudmundsson \& Hafsteinsson, 1997). Jenis asam, kekuatan ionik, $\mathrm{pH}$ yang digunakan akan mempengaruhi sifat-sifat pengembangan (swelling) dan kelarutan gelatin (Gomez \& Montero, 2001). Gelatin tipe A dihasilkan dari proses asam, yang umumnya diterapkan untuk bahan baku yang relatif lunak atau molekul kolagen yang mempunyai ikatan silang yang tidak terlalu kompleks.

Suhu ekstraksi sangat memegang peranan penting dalam ekstraksi gelatin. Suhu minimum dalam proses ekstraksi berkisar $40-50^{\circ} \mathrm{C}$ (Grossman \& Bergman 1991) dan suhu maksimum hingga $100^{\circ} \mathrm{C}$ (Viro, 1992). Untuk penggunaan dalam bahan pangan, kekuatan gel, viskositas dan titik leleh merupakan sifat khas gelatin yang sangat penting. Sifat-sifat ini dipengaruhi oleh beberapa faktor, seperti konsentrasi larutan gelatin, waktu pemanasan gel, suhu pemanasan gel, $\mathrm{pH}$ dan kandungan garam (Norland 1990; Osborne et al., 1990). Selain itu teknik ekstraksi seperti tingkat keasaman larutan perendaman, lama perendaman dan suhu ekstraksi diduga mempengaruhi sifat-sifat gelatin tersebut (Anon., 2002)

Tujuan dari penelitian ini adalah untuk mendapatkan suatu teknik untuk memproduksi gelatin dari kulit ikan patin sebagai bahan baku dengan melakukan penelitian terhadap penanganan bahan baku, penentuan kondisi yang terbaik untuk proses pengembangan kulit ikan dalam asam, penentuan suhu serta waktu ekstraksi sehingga diperoleh gelatin yang mempunyai rendemen yang tinggi serta memenuhi persyaratan kekuatan gel, viskositas maupun $\mathrm{pH}$ gelatin sebagai produk bahan pangan dan farmasi.

\section{BAHAN DAN METODE}

\section{Bahan}

Bahan utama yang digunakan pada penelitian ini adalah kulit ikan patin, yang diperoleh dari limbah industri pengolahan fillet ikan patin. Kulit ikan dimasukkan ke dalam peti yang telah disediakan dan diberi pecahan es sebagai medium pendingin. Kulit ikan tersebut segera dibawa ke Pusat Riset Pengolahan Produk dan Sosial Ekonomi Kelautan dan Perikanan. Bahan-bahan lainnya adalah asam sitrat dan aquades.

\section{Metode}

Kulit ikan patin dicuci dengan air bersih dan selanjutnya dilakukan perebusan (degreasing) yaitu untuk menghilangan lemak serta kotoran lain yang menempel pada kulit. Perebusan ini dilakukan selama
0,$5 ; 1 ; 2$ dan 5 menit pada suhu $80^{\circ} \mathrm{C}$. Kulit ikan selanjutnya disiram dengan air dingin, kemudian disikat pada bagian dalam kulit sehingga daging dan lemak yang melekat pada kulit hilang. Kulit ikan yang telah bersih dipotong menjadi ukuran $1,5-2,0 \mathrm{~cm}$. Kemudian dilakukan demineralisasi yang bertujuan untuk menghilangkan mineral pada kulit ikan sehingga diperoleh kulit yang mengembang (swelling). Demineralisasi dilakukan dengan merendam kulit selama 12, 24 dan 36 jam dalam larutan asam sitrat dengan $\mathrm{pH}$ yang diinginkan dengan perbandingan kulit ikan : asam sitrat adalah 1:4 (w/v). Larutan asam sitrat dibuat dengan melarutkan asam sitrat dalam aquades hingga $\mathrm{pH} 2,3$ dan 4 . Kulit kemudian dicuci dengan air mengalir sampai tercapai $\mathrm{pH}$ 6-7

Tahap berikutnya dilakukan ekstraksi untuk mengkonversi kolagen menjadi gelatin. Pada proses ekstraksi perbandingan antara kulit yang sudah swelling dengan air pengekstrak (aquades) adalah $1: 3$ (w/v). Suhu yang digunakan adalah $70^{\circ}$ dan $90^{\circ} \mathrm{C}$ dengan lama ekstraksi 2 jam. Hasil ekstraksi disaring menggunakan kapas dan kain saring blacu. Filtrat dituang ke dalam pan alumunium $48 \times 39 \mathrm{~cm}$ yang diberi alas plastik tahan panas High Density Polyethylene (HDPE) dengan ketebalan $0,6 \mathrm{~cm}$. Pengeringan dilakukan pada oven dengan suhu $50^{\circ} \mathrm{C}$ selama 36 48 jam sehingga diperoleh gelatin berbentuk lembaran. Proses ekstraksi gelatin dapat dilihat pada Gambar 1.

\section{Rancangan Percobaan}

Rancangan percobaan yang digunakan adalah rancangan acak lengkap faktorial dengan 3 faktor, yaitu $\mathrm{pH}$ perendaman $(\mathrm{A})$, lama perendaman $(B)$, dan suhu ekstraksi (C). Faktor pertama yaitu $\mathrm{pH}$ perendaman yang terdiri dari tiga taraf, yaitu $\mathrm{pH} 2$ (A1) ; 3 (A2) dan 4 (A3). Faktor yang kedua yaitu lama perendaman yang terdiri dari tiga taraf, yaitu 12 jam (B1), 24 jam (B2) dan 36 jam (B3). Faktor ke tiga adalah perlakuan suhu, yaitu suhu $70^{\circ} \mathrm{C}(\mathrm{C} 1)$ dan $90^{\circ} \mathrm{C}(\mathrm{C} 2)$ dengan waktu ekstraksi 2 jam.

Data yang diperoleh dianalisis dengan menggunakan analisis keragaman faktorial. Jika hasilnya berbeda nyata dilanjutkan dengan uji lanjut Duncan (Steel \& Torrie, 1993). Penelitian ini dilakukan dengan ulangan tiga kali.

\section{PENGAMATAN}

\section{Rendemen (AOAC, 1995)}

Rendemen diperoleh dari perbandingan bobot lembaran gelatin kering yang dihasilkan dengan bahan segar (kulit yang telah dibersihkan dari sisa daging dan lapisan lemak). 


\section{Kulit Ikan Patin Segar/ \\ Fresh Catfish Skin}

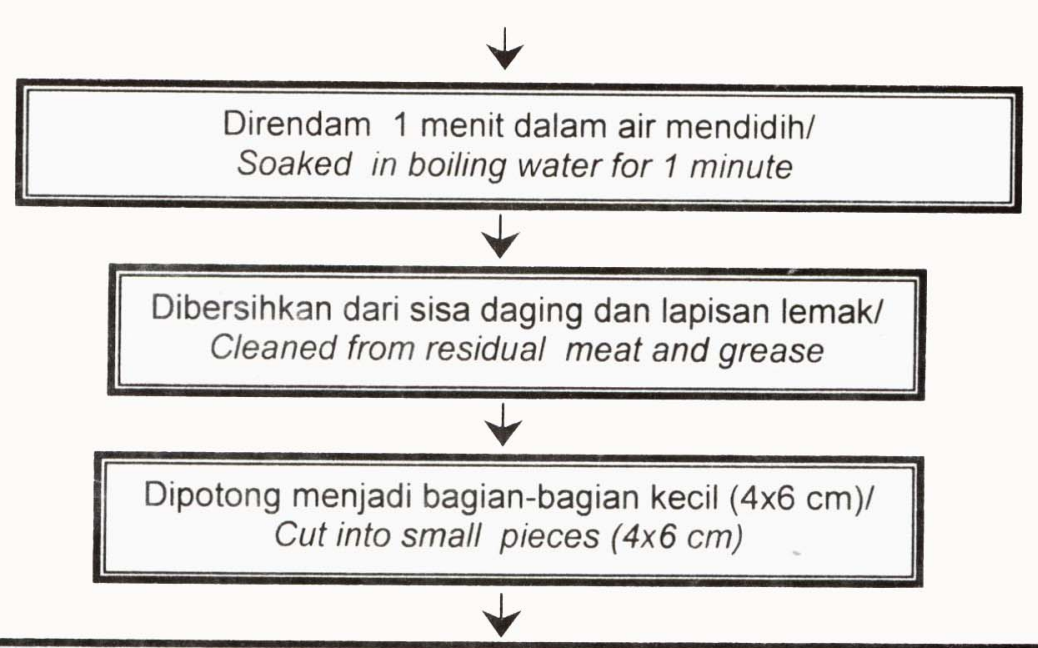

Direndam dalam larutan asam sitrat pada pH 2, 3 dan 4 selama 12, 24 dan 36 jam/ Soaked in citric acid solution at $\mathrm{pH}$ of 2,3 and 4 for 12,24 and 36 hours

Dicuci dengan air mengalir sampai $\mathrm{pH}$ netral (6-7)/ Washed in running water untill neutral $\mathrm{pH}(6-7)$

Kulit diekstraksi dalam waterbath pada suhu 70 dan $90^{\circ} \mathrm{C}$ selama $2 \mathrm{jam} /$ Extracted in waterbath at $70^{\circ} \mathrm{C}$ and $90^{\circ} \mathrm{C}$ for 2 hours

Ekstrak disaring untuk menghilangkan kotoran dengan menggunakan kapas dan kain saring/ Filtered to remove filth using cotton and cloth

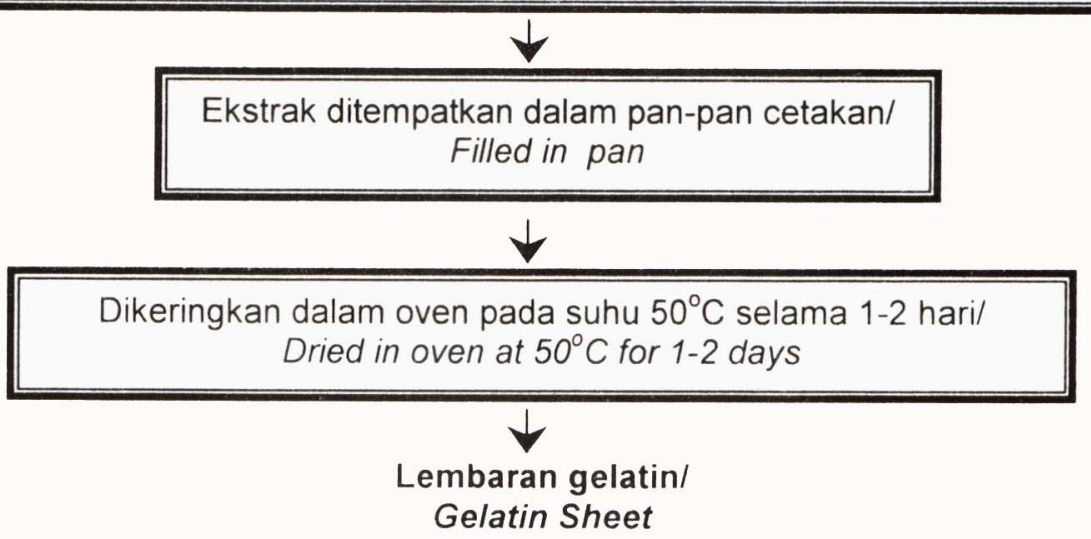

Gambar 1. Alur proses ekstraksi gelatin dari kulit ikan patin

Figure 1. Process flow of gelatin extraction from catfish skin. 


$$
\text { Rendemen }(\%)=\frac{\text { bobot gelatin kering }}{\text { bobot bahan segar }} \times 100 \%
$$

\section{Kekuatan gel (Wainewright dalam Ward \& Courts, 1977)}

Larutan gelatin dengan konsentrasi $6,67 \%$ (b/b) disiapkan dengan aquades. Larutan diambil sebanyak $15 \mathrm{ml}$ kemudian ditempatkan dalam wadah dengan volume $20 \mathrm{ml}$. Sampel diinkubasikan pada suhu $10^{\circ} \mathrm{C}$ selama $17 \pm 2$ jam, kemudian diukur dengan menggunakan curd meter. Hasil pengukuran berupa grafik, selanjutnya dihitung dengan rumus:

$$
\begin{aligned}
& \text { Kekuatan Gel }\left(\text { dyne } / \mathrm{cm}^{2}\right)=\frac{\mathrm{F}}{\mathrm{g}} \times 980 \\
& \text { Kekuatan Gel }(\text { bloom })=2,86 \times 10^{-3} \mathrm{G}+20 \\
& \text { Keterangan : } F=\text { tinggi grafik sebelum patah } \\
& g=\text { konstanta }(0,07) \\
& \mathrm{G}=\text { kekuatan gel }\left(\text { dyne } / \mathrm{cm}^{2}\right)
\end{aligned}
$$

\section{Viskositas (Wainewright dalam Ward \& Courts, 1977)}

Larutan gelatin dengan konsentrasi $6,67 \%(b / b)$ disiapkan dengan aquades kemudian diukur viskositasnya dengan menggunakan alat viskometer Brookfield. Pengukuran dilakukan pada suhu $60^{\circ} \mathrm{C}$ dengan laju geser 60 rpm menggunakan spindel 1. Hasil pengukuran dikalikan dengan faktor konversi, yaitu untuk spidel 1 faktor konversinya adalah 1 . Nilai viskositas dinyatakan dalam satuan centipoise (cps).

\section{Derajat Keasaman (pH) (Wainewright dalam Ward \& Courts, 1977)}

Laruțan gelatin dengan konsentrasi 6,67\% (b/b) disiapkan dengan aquades. Larutan sampel dipanaskan pada suhu $70^{\circ} \mathrm{C}$ dan dihomogenkan dengan magnetic stirrer, kemudian diukur derajat keasamannya pada suhu kamar dengan $\mathrm{pH}$ meter.

\section{HASIL DAN BAHASAN}

Berdasarkan hasil pengamatan diperoleh bahwa ikan patin rata-rata memiliki komposisi sebagai berikut: daging $54,2 \%$, tulang $12,4 \%$, kulit $4,5 \%$, kepala $20,6 \%$, isi perut $5,6 \%$ dan ekor $2,8 \%$. Dengan demikian bila 1 ton ikan patin diproduksi menjadi fillet akan diperoleh sekitar $45 \mathrm{~kg}$ kulit segar.

\section{Penanganan Kulit Ikan Patin}

Pelepasan bagian daging yang melekat pada kulit ikan patin dengan perlakuan perebusan selama 0,5 , 1, 2 dan 5 menit menunjukkan bahwa perebusan

\begin{tabular}{|c|c|c|}
\hline No. & $\begin{array}{l}\text { Lama perebusan } \\
80^{\circ} \mathrm{C} \text { (menit)l } \\
\text { Cooking time at } \\
80^{\circ} \mathrm{C} \text { (minutes) }\end{array}$ & $\begin{array}{l}\text { Deskripsi kulit ikan patin/ } \\
\text { Description of catfish skin }\end{array}$ \\
\hline 1. & 0.5 & $\begin{array}{l}\text { Kulit sangat keras, bagian daging sulit untuk dilepaskan dari kulit/Skin } \\
\text { was very hard, flesh was very hard to remove from catfish skin }\end{array}$ \\
\hline 2. & 1 & $\begin{array}{l}\text { Kulit cukup keras, bagian daging mudah untuk dilepaskan dari kulit/Skin } \\
\text { still hard but the flesh was easy to remove from catfish skin }\end{array}$ \\
\hline 3. & 2 & $\begin{array}{l}\text { Kulit lunak, bagian daging sangat mudah dilepaskan dari kulit/Skin was } \\
\text { soft and flesh was easy to remove from catfish skin }\end{array}$ \\
\hline 4. & 3 & $\begin{array}{l}\text { Kulit lunak, mudah sobek dan bagian daging sangat mudah dilepaskan } \\
\text { dari kulit/Skin was easily broken and flesh was easy to remove from } \\
\text { catfish skin }\end{array}$ \\
\hline 5. & 4 & $\begin{array}{l}\text { Kulit sangat lunak, mudah hancur dan bagian daging sangat mudah } \\
\text { dilepaskan dari kulit/Skin was so soft and easily broken and flesh was } \\
\text { easy to remove from catfish skin }\end{array}$ \\
\hline 6. & 5 & Kulit sangat lunak, mudah hancur/Skin was very soft and easily broken \\
\hline
\end{tabular}
selama 1 menit pada air $80^{\circ} \mathrm{C}$ sudah cukup mudah untuk melepaskan bagian daging yang melekat pada kulit (Tabel 1).

Tabel 1. Deskripsi pelepasan daging dari kulit ikan patin dengan metoda perebusan

Table 1. Description of releasing flesh residues from catfish skin by boiling method 
Perebusan mampu menurunkan kandungan lemak kulit (Tabel 2). Kulit yang direbus selama 30 detik dan 1 menit kandungan lemaknya turun dari 7,8\% menjadi masing-masing $5,2 \%$ dan $5,3 \%$. Pada perebusan selama 2 menit kandungan lemaknya menjadi $1,1 \%$, tetapi perebusan selama 2 menit menyebabkan kulit sangat mudah rusak sehingga untuk selanjutnya dalam penelitian ini menggunakan perebusan selama 1 (satu) menit.

\section{Rendemen Gelatin}

Perhitungan rendemen dilakukan untuk mengetahui persentase gelatin yang dihasilkan dari tunggal. Sementara pada perendaman dengan larutan $\mathrm{pH} 4$, diperoleh rendemen gelatin yang tidak terlalu tinggi. Hal ini disebabkan karena konsentrasi asam pada larutan tersebut tidak mampu mengubah serat kolagen kulit menjadi rantai tunggal, sehingga tidak terjadi pengembangan selama perendaman.

Hal yang sama ditunjukkan dari hasil perendaman kulit dalam larutan dengan $\mathrm{pH} 2$, dengan rendemen gelatin yang sangat rendah, yang disebabkan karena pada $\mathrm{pH}$ tersebut protein terutama kolagen dari kulit telah mengalami kerusakan. Gejala ini ditunjukkan dari hasil pengamatan, yaitu kulit yang direndam dalam larutan asam sitrat $\mathrm{pH} 2$ menjadi terurai dan bobot

Tabel 2. Analisis proksimat kulit ikan patin (\%)

Table 2. Proximate analysis of catfish skin (\%)

\begin{tabular}{ccccc}
\hline $\begin{array}{c}\text { Kode Contoh/ } \\
\text { Sample code }\end{array}$ & $\begin{array}{c}\text { Airl } \\
\text { Moisture }\end{array}$ & $\begin{array}{c}\text { Abul } \\
\text { Ash }\end{array}$ & Protein & $\begin{array}{c}\text { Lemakl } \\
\text { Fat }\end{array}$ \\
\hline $\mathrm{KPS}_{0}$ & 34.48 & 0.20 & 20.56 & 7.78 \\
$\mathrm{KRM}_{1}$ & 41.82 & 0.08 & 20.09 & 5.17 \\
$\mathrm{KRM}_{2}$ & 40.16 & 0.07 & 19.87 & 5.28 \\
$\mathrm{KRM}_{3}$ & 41.25 & 0.07 & 19.78 & 1.05 \\
$\mathrm{KRM}_{4}$ & 34.91 & 0.07 & 19.06 & 1.41 \\
\hline
\end{tabular}

Keterangan/Note:

KPS: Kulit Patin Segar /fresh catfish skin

KRM : Kulit Patin Rebus 30 detik/ catfish skin boiled for 30 second

$\mathrm{KRM}_{2}$ : Kulit Patin Rebus 1 menit/ catfish skin boiled for 1 minute

$\mathrm{KRM}_{3}$ : Kulit Patin Rebus 2 menit/ catfish skin boiled for 2 minutes

$\mathrm{KRM}_{4}$ : Kulit Patin Rebus 5 menit/ catfish skin boiled for 5 minutes

kulit ikan patin segar berdasarkan $\mathrm{pH}$ larutan perendaman, lama perendaman dan suhu ekstraksi.

Hasil analisis ragam menunjukkan bahwa $\mathrm{pH}$ larutan perendaman dan lama perendaman berpengaruh sangat nyata $(p<0,01)$ terhadap rendemen gelatin yang dihasilkan. Demikian pula interaksi antar perlakuan yang diterapkan menunjukkan pengaruh sangat nyata. Namun suhu ekstraksi tidak berpengaruh nyata $(p>0,05)$ terhadap rendemen gelatin yang dihasilkan. Pengaruh $\mathrm{pH}$ larutan perendaman, lama perendaman dan suhu ekstraksi terhadap rendemen gelatin yang dihasilkan disajikan pada Gambar 2, yang memperlihatkan ratarata rendemen gelatin yang tinggi pada perendaman $\mathrm{pH} 3$, selanjutnya $\mathrm{pH} 4$ dan yang terendah pada $\mathrm{pH}$ 2. Hal ini disebabkan karena pada perendaman $\mathrm{pH} 3$, kulit menjadi mengembang sebagaimana tujuan dari perendaman tersebut dan ini menunjukkan bahwa kolagen yang ada pada kulit tersebut ikatannya berubah menjadi ikatan rantai tunggal. Sebagaimana dinyatakan Ward \& Court (1977) bahwa asam mampu mengubah serat kolagen triple helix menjadi rantai kulit setelah perendaman menjadi berkurang. Menurut Lehninger (1982) protein akan rusak terdenaturasi tidak hanya oleh panas, tetapi juga oleh pengaruh $\mathrm{pH}$, yang akan mengubah struktur utama rantai peptida pada protein. Jika protein terdenaturasi, susunan ikatan rantai polipeptida terganggu dan molekul protein terbuka menjadi struktur acak dan selanjutnya terkoagulasi, sehingga jumlah kolagen yang terekstraksi lebih rendah

Hasil analisis, menunjukkan bahwa semakin lama perendaman maka rendemen gelatin yang dihasilkan semakin rendah. Rendemen yang tertinggi rata-rata diperoleh dari perendaman selama $12 \mathrm{jam}$, selanjutnya 24 jam dan yang terendah dengan lama perendaman $36 \mathrm{jam}$. Hal ini disebabkan karena semakin lama perendaman maka $\mathrm{pH}$ larutan perendaman semakin meningkat mendekati $\mathrm{pH}$ netral, sehingga penguraian tidak terjadi lagi meskipun perendaman masih berlanjut

Hasil analisis rata-rata rendemen berdasarkan suhu ekstraksi, menunjukkan bahwa antara suhu ekstraksi 
$70^{\circ} \mathrm{C}$ dan $90^{\circ} \mathrm{C}$ tidak berbeda nyata pada tingkat kepercayaan $95 \%$. Namun secara umum, rata-rata rendemen dengan suhu ekstraksi $90^{\circ} \mathrm{C}$ lebih tinggi dibanding suhu ekstraksi $70^{\circ} \mathrm{C}$. Hal ini disebabkan karena semakin tinggi suhu ekstraksi maka kolagen yang terurai menjadi filtrat gelatin semakin banyak. Uji lanjut menggunakan uji beda jarak berganda Duncan (BJBD), menunjukkan bahwa rendemen gelatin yang dihasilkan dari perlakuan perendaman dalam larutan $\mathrm{pH} 3$ dengan suhu ekstraksi $90^{\circ} \mathrm{C}$ untuk semua waktu perendaman tidak berbeda nyata dengan rendemen gelatin yang dihasilkan dari perlakuan larutan perendaman $\mathrm{pH} 3$, lama perendaman $12 \mathrm{jam}$ dengan suhu ekstraksi $70^{\circ} \mathrm{C}$, yaitu pada perlakuan tersebut diperoleh rendemen gelatin tertinggi (Tabel 3)

\section{Viskositas Gelatin}

Analisis ragam viskositas gelatin menunjukkan bahwa $\mathrm{pH}$ larutan perendaman, lama perendaman, suhu ekstraksi dan interaksi antar perlakuan berpengaruh sangat nyata terhadap viskositas gelatin yang dihasilkan. Rata-rata nilai viskositas gelatin yang tertinggi diperoleh pada perendaman dengan larutan $\mathrm{pH} 3$ dan terendah diperoleh dari perendaman larutan $\mathrm{pH}$ 4. Hal ini menunjukkan bahwa kekentalan dari larutan gelatin yang dihasilkan dengan perendaman $\mathrm{pH} 3$ cenderung lebih baik dibanding perendaman pada $\mathrm{pH} 2$ dan 4.

Berdasarkan lama perendaman, tampak bahwa rata-rata nilai viskositas cenderung menurun dengan semakin lamanya perendaman. Hal ini menunjukkan bahwa kekentalan gelatin yang dihasilkan cenderung semakin rendah dengan semakin lamanya proses perendaman. Berdasarkan suhu ekstraksi, rata-rata nilai viskositas gelatin yang dihasilkan dari suhu $90^{\circ} \mathrm{C}$ lebih tinggi dibanding suhu ekstraksi $70^{\circ} \mathrm{C}$

Hasil uji lanjut menggunakan BJBD (Tabel 4), menunjukkan bahwa perlakuan perendaman dengan larutan $\mathrm{pH} 3$, lama perendaman 12 jam dengan suhu

Tabel 3. Hasil uji BJBD dari rendemen gelatin (\% terhadap bobot bahan) dari kulit ikan patin

Table 3. Duncan's multiple range test of yield (\% of raw material weight) of catfish skin gelatin

\begin{tabular}{|c|c|c|}
\hline $\begin{array}{l}\text { Perlakuan } \\
\text { Treatment }\end{array}$ & $\begin{array}{c}\text { Rerata Rendemen (\%)/ } \\
\text { Means of Yield (\%) }\end{array}$ & $\begin{array}{c}\text { BJBD/ } \\
\text { Duncan's multiple range test }\end{array}$ \\
\hline A2B1C1 & 10.01 & A \\
\hline $\mathrm{A} 2 \mathrm{~B} 1 \mathrm{C} 2$ & 9.62 & $A B$ \\
\hline $\mathrm{A} 2 \mathrm{~B} 2 \mathrm{C} 2$ & 9.34 & $A B C$ \\
\hline $\mathrm{A} 2 \mathrm{~B} 3 \mathrm{C} 2$ & 9.08 & $A B C$ \\
\hline $\mathrm{A} 3 \mathrm{~B} 2 \mathrm{C} 2$ & 8.71 & B C D \\
\hline $\mathrm{A} 2 \mathrm{~B} 2 \mathrm{C} 1$ & 8.39 & CDE \\
\hline $\mathrm{A} 3 \mathrm{~B} 1 \mathrm{C} 1$ & 7.75 & DEF \\
\hline $\mathrm{A} 3 \mathrm{~B} 2 \mathrm{C} 1$ & 7.65 & E F \\
\hline $\mathrm{A} 3 \mathrm{~B} 1 \mathrm{C} 2$ & 7.47 & E F \\
\hline $\mathrm{A} 2 \mathrm{~B} 3 \mathrm{C} 1$ & 7.08 & $F G$ \\
\hline A3B3C 1 & 6.38 & G \\
\hline АЗВ3С2 & 4.99 & $\mathrm{H}$ \\
\hline $\mathrm{A} 1 \mathrm{~B} 1 \mathrm{C} 1$ & 1.84 & 1 \\
\hline $\mathrm{A} 1 \mathrm{~B} 1 \mathrm{C} 2$ & 1.67 & 1 \\
\hline $\mathrm{A} 1 \mathrm{~B} 3 \mathrm{C} 2$ & 0.93 & $\mathrm{IJ}$ \\
\hline $\mathrm{A} 1 \mathrm{~B} 2 \mathrm{C} 2$ & 0.60 & J \\
\hline $\mathrm{A} 1 \mathrm{~B} 2 \mathrm{C} 1$ & 0.58 & $\mathrm{~J}$ \\
\hline $\mathrm{A} 1 \mathrm{~B} 3 \mathrm{C} 1$ & 0.29 & J \\
\hline
\end{tabular}

Keterangan/Note: Nilai dalam kolom yang diikuti huruf yang sama secara statistik tidak berbeda nyata $(P>0,05) /$ values in the column followed by similar characters are insignificantly different $(P>0.05)$

A : Perlakuan $\mathrm{pH} / \mathrm{pH}$ treatment $(1,2,3=\mathrm{pH} 2 ; \mathrm{pH} 3 ; \mathrm{pH} 4)$

$\mathrm{B}$ : waktu pengembangan/swelling time $(1,2,3=12 \mathrm{jam} /$ hours; $24 \mathrm{jam} / \mathrm{hours} ; 36 \mathrm{jam} / \mathrm{hours})$.

C : perlakuan suhu/temperature treatment $\left(1,2=70^{\circ} \mathrm{C}, 90^{\circ} \mathrm{C}\right)$. 
Tabel 4. Hasil uji beda jarak berganda Duncan (BJBD) terhadap viskositas gelatin kulit patin

Table 4. Duncan's multiple range test on viscosity of gelatin from catfish skin

\begin{tabular}{|c|c|c|}
\hline $\begin{array}{l}\text { Perlakuan/ } \\
\text { Treatment }\end{array}$ & $\begin{array}{l}\text { Re rata Viskositas (cps)/ } \\
\text { Means Viscosity (cps) }\end{array}$ & $\begin{array}{c}\text { BJBDI } \\
\text { Duncan's multiple range test }\end{array}$ \\
\hline $\mathrm{A} 2 \mathrm{~B} 1 \mathrm{C} 2$ & 10.00 & A \\
\hline $\mathrm{A} 2 \mathrm{~B} 2 \mathrm{C} 2$ & 7.00 & B \\
\hline $\mathrm{A} 1 \mathrm{~B} 1 \mathrm{C} 1$ & 6.90 & B \\
\hline $\mathrm{A} 3 \mathrm{~B} 1 \mathrm{C} 2$ & 6.35 & B \\
\hline $\mathrm{A} 2 \mathrm{~B} 1 \mathrm{C} 1$ & 5.70 & B C \\
\hline $\mathrm{A} 2 \mathrm{~B} 3 \mathrm{C} 1$ & 4.75 & C D \\
\hline $\mathrm{A} 2 \mathrm{~B} 3 \mathrm{C} 2$ & 4.15 & DE \\
\hline A3B3C2 & 4.00 & $D E F$ \\
\hline $\mathrm{A} 1 \mathrm{~B} 2 \mathrm{C} 1$ & 3.85 & $D E F$ \\
\hline $\mathrm{A} 2 \mathrm{~B} 2 \mathrm{C} 1$ & 3.80 & $D E F$ \\
\hline $\mathrm{A} 1 \mathrm{~B} 1 \mathrm{C} 2$ & 3.75 & $D E F$ \\
\hline $\mathrm{A} 1 \mathrm{~B} 3 \mathrm{C} 2$ & 3.65 & $D E F$ \\
\hline A3B3C1 & 3.55 & $D E F$ \\
\hline $\mathrm{A} 1 \mathrm{~B} 2 \mathrm{C} 2$ & 3.50 & $D E F$ \\
\hline $\mathrm{A} 1 \mathrm{~B} 3 \mathrm{C} 1$ & 3.40 & $D E F$ \\
\hline $\mathrm{A} 3 \mathrm{~B} 2 \mathrm{C} 1$ & 3.25 & E F \\
\hline $\mathrm{A} 3 \mathrm{~B} 2 \mathrm{C} 2$ & 3.10 & EF \\
\hline $\mathrm{A} 3 \mathrm{~B} 1 \mathrm{C} 1$ & 2.65 & $\mathrm{~F}$ \\
\hline
\end{tabular}

Keterangan/Note: Nilai dalam kolom yang diikuti huruf yang sama secara statistik tidak berbeda nyata $(P>0,05) /$ values in the column followed by similar characters are insignificantly different $(P>0.05)$

A : Perlakuan $\mathrm{pH} / \mathrm{pH}$ treatment $(1,2,3=\mathrm{pH} 2 ; \mathrm{pH} 3 ; \mathrm{pH} 4)$.

B : waktu pengembangan/swelling time $(1,2,3=12$ jam/hours; 24 jam/hours; 36 jam/hours $)$

C : perlakuan suhu/temperature treatment $\left(1,2=70^{\circ} \mathrm{C}, 90^{\circ} \mathrm{C}\right)$.

ekstraksi $90^{\circ} \mathrm{C}(\mathrm{A} 2 \mathrm{~B} 1 \mathrm{C} 2)$ berbeda nyata dengan semua perlakuan yang diterapkan, dan diperoleh nilai viskositas yang tertinggi yaitu sekitar 10,0 cps.

Perlakuan yang terbaik berdasarkan nilai viskositas adalah perendaman dengan larutan $\mathrm{pH} 3$ dan lama perendaman 12 jam menggunakan suhu ekstraksi $90^{\circ} \mathrm{C}$, karena untuk pembentukan gel diperlukan viskositas yang tinggi

Dalam penggunaannya sebagai gelatin mutu pangan dan farmasi maka gelatin yang dihasilkan memenuhi persyaratan viskositas, yaitu lebih besar atau sama dengan 4,5 cps (Anon., 2003).

\section{pH Gelatin}

Pengukuran nilai $\mathrm{pH}$ larutan gelatin penting dilakukan, karena $\mathrm{pH}$ larutan gelatin mempengaruhi sifat-sifat gelatin yang lainnya seperti viskositas dan kekuatan gel (Astawan et al., 2002). pH gelatin berdasarkan standar mutu gelatin secara umum diharapkan mendekati $\mathrm{pH}$ netral $(\mathrm{pH} 7)$.

Hasil analisis ragam menunjukkan bahwa $\mathrm{pH}$ larutan perendaman berpengaruh sangat nyata terhadap $\mathrm{pH}$ gelatin yang dihasilkan. Suhu ekstraksi berpengaruh nyata terhadap $\mathrm{pH}$ gelatin, sedangkan lama perendaman tidak berpengaruh nyata. Nilai $\mathrm{pH}$ gelatin semakin naik dengan makin tingginya $\mathrm{pH}$ larutan perendaman. Hal ini disebabkan karena semakin tinggi $\mathrm{pH}$ larutan perendaman, maka konsentrasi larutan asam yang diserap oleh kulit selama perendaman semakin rendah dan sebaliknya. Gejala ini ditunjukkan dari hasil pengamatan, untuk larutan perendaman $\mathrm{pH} 2$ berubah menjadi $\mathrm{pH} 3$ setelah perendaman, larutan $\mathrm{pH} 3$ berubah menjadi $\mathrm{pH} 4-5$, dan $\mathrm{pH} 4$ berubah menjadi $\mathrm{pH}$ 5-6. Dengan demikian rendahnya $\mathrm{pH}$ gelatin yang dihasilkan dari larutan perendaman $\mathrm{pH} 2$ disebabkan oleh pencucian yang dilakukan setelah perendaman tidak mampu 
menghilangkan semua larutan asam yang diserap kulit selama perendaman, sehingga gelatin yang dihasilkan mempunyai $\mathrm{pH}$ yang rendah.

Uji lanjut BJBD (Tabel 5) nilai rata-rata $\mathrm{pH}$ gelatin yang dihasilkan dari larutan perendaman $\mathrm{pH} 3$ tidak menunjukkan perbedaan nyata dengan $\mathrm{pH} 4$, sedangkan nilai rata-rata $\mathrm{pH}$ gelatin yang dihasilkan dengan larutan perendaman $\mathrm{pH} 2$ berbeda nyata dengan $\mathrm{pH}$ gelatin yang dihasilkan dari larutan perendaman $\mathrm{pH} 3$ dan $\mathrm{pH} 4$. Nilai $\mathrm{pH}$ larutan gelatin yang dihasilkan dari larutan perendaman $\mathrm{pH} 3$ dan $\mathrm{pH} 4$ berada pada kisaran $6,7-7,2$, sedangkan nilai $\mathrm{pH}$ gelatin dari larutan perendaman $\mathrm{pH} 2$ berkisar 4,35,9 .

Standar mutu gelatin di Indonesia tidak mencantumkan $\mathrm{pH}$ sebagai salah satu persyaratan
(SNI, 1995), sedangkan standar pH untuk gelatin mutu pangan dan farmasi menurut Anon., (2003) berkisar 5,5-7,0. Dengan demikian gelatin yang dihasilkan dari perlakuan perendaman dalam larutan $\mathrm{pH} 3$ dan 4 memenuhi persyaratan sebagai bahan pangan dan farmasi.

\section{Kekuatan Gel Gelatin}

Kekuatan gel sangat penting dalam penentuan perlakuan yang terbaik dalam proses ekstraksi gelatin, karena salah satu sifat penting gelatin adalah mampu mengubah cairan menjadi padatan atau mengubah bentuk sol menjadi gel yang bersifat reversibel. Kemampuan inilah yang menyebabkan gelatin sangat luas penggunaannya, baik dalam bidang pangan maupun non pangan.

Tabel 5. Hasil uji beda jarak berganda Duncan (BJBD) terhadap pH gelatin kulit patin

Table 5. Duncan's multiple range test on $\mathrm{pH}$ gelatin from catfish skin

\begin{tabular}{|c|c|c|c|}
\hline $\begin{array}{l}\text { Perlakuan/ } \\
\text { Treatment }\end{array}$ & $\begin{array}{c}\text { Rerata } \mathrm{pH} / \\
\text { Means of } \mathrm{pH}\end{array}$ & Duncan's & $\begin{array}{l}\text { BJBD/ } \\
\text { multiple range test }\end{array}$ \\
\hline A3B3C1 & 7.20 & A & \\
\hline A3B1C1 & 7.20 & $A$ & \\
\hline $\mathrm{A} 2 \mathrm{~B} 2 \mathrm{C} 2$ & 7.10 & $A$ & \\
\hline $\mathrm{A} 3 \mathrm{~B} 1 \mathrm{C} 2$ & 7.10 & $A$ & \\
\hline $\mathrm{A} 3 \mathrm{~B} 2 \mathrm{C} 2$ & 7.05 & A & \\
\hline A3B2C1 & 7.05 & A & \\
\hline $\mathrm{A} 2 \mathrm{~B} 1 \mathrm{C} 2$ & 7.00 & A & \\
\hline $\mathrm{A} 2 \mathrm{~B} 1 \mathrm{C} 1$ & 6.95 & A & \\
\hline A3B3C2 & 6.95 & A & \\
\hline $\mathrm{A} 2 \mathrm{~B} 2 \mathrm{C} 1$ & 6.90 & A & \\
\hline $\mathrm{A} 2 \mathrm{~B} 3 \mathrm{C} 1$ & 6.85 & A & \\
\hline $\mathrm{A} 2 \mathrm{~B} 3 \mathrm{C} 2$ & 6.70 & A & \\
\hline $\mathrm{A} 1 \mathrm{~B} 1 \mathrm{C} 1$ & 5.90 & B & \\
\hline $\mathrm{A} 1 \mathrm{~B} 3 \mathrm{C} 1$ & 5.70 & $\mathrm{~B}$ & \\
\hline $\mathrm{A} 1 \mathrm{~B} 2 \mathrm{C} 2$ & 5.50 & B C & \\
\hline $\mathrm{A} 1 \mathrm{~B} 2 \mathrm{C} 1$ & 5.40 & B C & \\
\hline $\mathrm{A} 1 \mathrm{~B} 3 \mathrm{C} 2$ & 4.90 & C & D \\
\hline $\mathrm{A} 1 \mathrm{~B} 1 \mathrm{C} 2$ & 4.30 & & $\mathrm{D}$ \\
\hline
\end{tabular}

Keterangan/Note: Nilai dalam kolom yang diikuti huruf yang sama secara statistik tidak berbeda nyata $(P>0,05) /$ values in the column followed by similar characters are insignificantly different $(P>0.05)$

A : Perlakuan $\mathrm{pH} / \mathrm{pH}$ treatment $(1,2,3=\mathrm{pH} 2 ; \mathrm{pH} 3 ; \mathrm{pH} 4)$.

$\mathrm{B}$ : waktu pengembangan/swelling time $(1,2,3=12 \mathrm{jam} /$ hours; $24 \mathrm{jam} /$ hours; $36 \mathrm{jam} / \mathrm{hours})$

C : perlakuan suhu/temperature treatment $\left(1,2=70^{\circ} \mathrm{C}, 90^{\circ} \mathrm{C}\right)$. 
Hasil analisis ragam kekuatan gel dari gelatin yang dihasilkan menunjukkan bahwa $\mathrm{pH}$ larutan perendaman, lama perendaman, suhu ekstraksi serta interaksi antar perlakuan berpengaruh sangat nyata terhadap kekuatan gel. Rata-rata kekuatan gel gelatin tertinggi diperoleh dari $\mathrm{pH} 3$, dan terendah diperoleh dari $\mathrm{pH} 4$, kecuali untuk lama perendaman 24 jam. Hal ini menunjukkan bahwa secara umum mutu gelatin yang diperoleh dari perendaman larutan $\mathrm{pH} 4$ lebih rendah dibanding larutan perendaman $\mathrm{pH} 2$ dan $\mathrm{pH} 3$
Hasil uji lanjut menggunakan BJBD (Tabel 6) menunjukkan bahwa untuk perlakuan perendaman larutan $\mathrm{pH} 3$ selama 12 jam dengan suhu ekstraksi $90^{\circ} \mathrm{C}$ berbeda nyata dengan semua perlakuan yang diterapkan. Pada perlakuan ini diperoleh nilai rata-rata kekuatan gel gelatin yang tertinggi yaitu 263,3 bloom.

Standar kekuatan gel untuk gelatin mutu pangan dibagi dalam tiga kelas yaitu kelas $\mathrm{A}, \mathrm{B}$ dan $\mathrm{C}$ masingmasing dengan nilai 220, 180 dan 100 bloom sedangkan untuk bahan farmasi dibagi dalam kelas

Tabel 6. Hasil uji beda jarak berganda Duncan (BJBD) terhadap kekuatan gel gelatin kulit patin

Table 6. Duncan's multiple range test on gel strength of gelatin from catfish skin

\begin{tabular}{|c|c|c|}
\hline $\begin{array}{l}\text { Perlakuan/ } \\
\text { Treatment }\end{array}$ & $\begin{array}{c}\text { Rerata Kekuatan Gel (bloom)/ } \\
\text { Gel strength means (bloom) }\end{array}$ & $\begin{array}{c}\text { BJBDI } \\
\text { (Duncan's multiple range test) }\end{array}$ \\
\hline $\mathrm{A} 2 \mathrm{~B} 1 \mathrm{C} 2$ & 263.25 & A \\
\hline $\mathrm{A} 2 \mathrm{~B} 3 \mathrm{C} 2$ & 210.19 & B \\
\hline $\mathrm{A} 2 \mathrm{~B} 3 \mathrm{C} 1$ & 195.61 & B \\
\hline $\mathrm{A} 1 \mathrm{~B} 1 \mathrm{C} 2$ & 169.72 & B C \\
\hline $\mathrm{A} 1 \mathrm{~B} 2 \mathrm{C} 1$ & 140.12 & CD \\
\hline $\mathrm{A} 2 \mathrm{~B} 1 \mathrm{C} 1$ & 138.12 & $C D$ \\
\hline $\mathrm{A} 3 \mathrm{~B} 2 \mathrm{C} 2$ & 137.12 & CDE \\
\hline $\mathrm{A} 1 \mathrm{~B} 3 \mathrm{C} 1$ & 136.55 & CDE \\
\hline АЗВ3C 1 & 134.38 & CDE \\
\hline A3B3C2 & 129.71 & CDE \\
\hline $\mathrm{A} 3 \mathrm{~B} 1 \mathrm{C} 2$ & 105.01 & DEF \\
\hline $\mathrm{A} 1 \mathrm{~B} 3 \mathrm{C} 2$ & 100.08 & $D E F G$ \\
\hline $\mathrm{A} 3 \mathrm{~B} 1 \mathrm{C} 1$ & 98.07 & $D E F G$ \\
\hline $\mathrm{A} 1 \mathrm{~B} 2 \mathrm{C} 2$ & 89.50 & EFG \\
\hline $\mathrm{A} 2 \mathrm{~B} 2 \mathrm{C} 2$ & 78.35 & F G \\
\hline $\mathrm{A} 1 \mathrm{~B} 1 \mathrm{C} 1$ & 76.06 & F G \\
\hline $\mathrm{A} 3 \mathrm{~B} 2 \mathrm{C} 1$ & 62.19 & F G \\
\hline $\mathrm{A} 2 \mathrm{~B} 2 \mathrm{C} 1$ & 54.32 & G \\
\hline
\end{tabular}

Keterangan/Note: Nilai dalam kolom yang diikuti huruf yang sama secara statistik tidak berbeda nyata $(P>0,05) /$ values in the column followed by similar characters are insignificantly different $(P>0.05)$

A : Perlakuan $\mathrm{pH} / \mathrm{pH}$ treatment $(1,2,3=\mathrm{pH} 2 ; \mathrm{pH} 3 ; \mathrm{pH} 4)$.

B : waktu pengembangan/swelling time $(1,2,3=12 \mathrm{jam} / \mathrm{hours;} 24 \mathrm{jam} / \mathrm{hours} ; 36 \mathrm{jam} / \mathrm{hours})$.

C : perlakuan suhu/temperature treatment $\left(1,2=70^{\circ} \mathrm{C}, 90^{\circ} \mathrm{C}\right)$

Berdasarkan lama perendaman, tampak bahwa nilai kekuatan gel untuk perendaman 12 jam dan 36 jam rata-rata lebih tinggi dari perendaman 24 jam terutama untuk perendaman dengan larutan $\mathrm{pH} 3$. Sementara berdasarkan suhu ekstraksi terlihat bahwa rata-rata nilai kekuatan gel gelatin yang diekstraksi pada suhu $90^{\circ} \mathrm{C}$ lebih tinggi dibanding gelatin yang diekstraksi pada suhu $70^{\circ} \mathrm{C}$. Hal ini disebabkan karena kolagen pada kulit lebih banyak terekstraksi dengan semakin tingginya suhu ekstraksi, sehingga kekuatan gel gelatin cenderung lebih baik spesial, kelas 1, 2 dan 3 yang masing-masing mempunyai kekuatan gel 240, 200, 160 dan 140 bloom (Anonym, 2003)

\section{KESIMPULAN}

Untuk menurunkan kandungan lemak pada kulit ikan patin sebagai bahan baku untuk gelatin dapat dilakukan dengan perebusan dalam air dengan suhu $80^{\circ} \mathrm{C}$ selama satu menit. Kulit patin cukup baik diolah menjadi gelatin dengan kombinasi perlakuan 
perendaman dalam larutan asam sitrat dengan $\mathrm{pH} 3$ selama 12 jam dan suhu ekstraksi $90^{\circ} \mathrm{C}$. Dengan perlakuan tersebut diperoleh rendemen gelatin sebesar $9,63 \%$, viskositas $10,0 \mathrm{cps}$, kekuatan gel 263,3 bloom dan $\mathrm{pH} 6,7$. Gelatin yang dihasilkan memenuhi persyaratan gelatin mutu pangan kelas $A$ dan memenuhi persyaratan gelatin untuk farmasi kelas satu

\section{SARAN}

Masih perlu dilakukan usaha-usaha untuk meningkatkan rendemen gelatin yang diperoleh menjadi lebih tinggi terutama dalam penanganan bahan baku maupun dalam suhu ekstraksi, karena pada penggunaan suhu yang tidak tepat kemungkinan banyak kolagen yang terlarut dalam air perebusan.

\section{DAFTAR PUSTAKA}

Anonymous. 2002. Gelatin Food Science. Gelatin. http:/ /www.gelatin.co.za/gltn1.html

Anonymous. 2003. Norland Product. Gelatin. http:// www. norlandprod.com/techrpts/Ediblegelatin.htm

AOAC. 1995. Official Methods of Analysis of The Association of Official Analytical Chemist. Inc, Washington, DC.

Astawan ,M.P., Hariyadi, A. dan Mulyani. 2002. Analisis sifat reologi gelatin dari kulit ikan cucut. J. Teknol. dan Industri Pangan 13 (1):38-46.

Gomez,G.M.C and Montero. P. 2001. Extraction of gelatin from megrim (Lepidorhombus boscii) skins with several organic acids. J. Food Sci. 66 (2): 213-216.

Grossman, S. and Bergman, M. 1991. Process for the Production of Gelatin from Fish Skins. European Paten Application 0436266 A1.

Grossman, S and Bergman, M. 1992. Process for the Production of Gelatin From Fish Skins. US Patent $5,093,474$

Gudmundsson, M and Hafsteinsson, H. 1997. Gelatin from cod skin affected by chemical teatments. J. Food Sci 62(1): 37-39

Kimura Z, Zhum, X.P., Matsui, R., Shijoh, M., Takamizawa, S. 1988. Characterization of fish muscle type I collagen. J. Food Sci. 53:1315-1318.
Lehninger. 1982. Dasar-Dasar Biokimia. Jilid I. Terjemahan. Thenawijaya M. Erlangga, Jakarta: $p$. 167-188

Montero,P., Borderias, J., Turnay., J. and Leyzarbe, M.A. 1990. Characterization of hake (Merluccius merluccius L.) and trout (Salmo irideus Gibb.) Collagen. J. Agric. Food Chem. 38(3):604-609

Montero,P., Alvared, C., Marti, M.A. and Borderias, A.J 1995. Plaice skin collagen extraction and functional properties. J. Food Sci 60 (1): 1-3.

Norland, R. E. 1990. Fish gelatin. In: Voight MN. and Botta J.K. (ed.). Advances in Fisheries Technology and Biotechnology for Increased Profitability. Lancaster, Pa.: Technomic Pub. Co : 325-333.

Osborne, K., Voight, M.N., and Hall, D.E. 1990. Utilisation of lumpfish carcasses for production of gelatin. In Voight M.N. and Botta J.K. (eds). Advances in Fisheries Technology and Biotechnology for Increased Profitability. Lancaster, $\mathrm{Pa}$.: Technomic Pub Co: $143-150$

Pelu, H., Harwanti, S., dan Chasanah, E. 1998. Ekstraksi gelatin dari kulit ikan tuna melalui proses asam Jurnal Penelitian Perikanan Indonesia 4 (2): 66-74 BPTP, Jakarta

Sato, K., Ohashi, C., Ohtsuki, K. and Kawabata, M. 1991 Type $V$ collagen in trout (Salmo gaidneri) muscle and its solubility change during chilled storage of muscle. J. Agric. Food Chem. 39:1222-1225.

SNI 06-3735. 1.995. Mutu dan Cara Uji Gelatin. Dewan Standarisasi Nasional, Jakarta.

Steel, R.G.D. dan Torrie, J. H. 1993. Prinsip dan Prosedur Statistika Suatu Pendekatan Biometri . Cetakan ke3. PT Gramedia Pustaka Umum. Jakarta: 187-194.

Viro, F. 1992. Gelatin. In Hui Y.H. (ed.). Encyclopedia of Food Science and Technology 2. John Wiley and Sons, Inc., Toronto.

Wainewright, F.W. 1977. Physical Test for Gelatin and Gelatin Products. In Ward, A. G. and Gourts, A. (eds.) The science and Technology of Gelatin. Academic Press, New York. p. 507-532

Ward, A.G. and Courts, A. 1977. The Science and Technology of Gelatin. Academic Press, New York.

Yustika, R. 2000. Pembuatan dan Analisis Sifat Kimia Gelatin dari Kulit dan Tulang Ikan Cucut. Skripsi IPB $69 \mathrm{pp}$ 